\title{
The Protective Influence of Selenium on Oxidant Disturbances in Brain of Rats Exposed to Lithium
}

\author{
M. KIELCZYKOWSKA ${ }^{1}$, J. KOCOT ${ }^{1}$, A. LEWANDOWSKA ${ }^{1}$, R. ŻELAZOWSKA $^{1}$, \\ I. MUSIK $^{1}$
}

${ }^{1}$ Chair and Department of Medical Chemistry, Medical University of Lublin, Lublin, Poland

Received September 17, 2014

Accepted December 12, 2014

On-line March 24, 2015

\begin{abstract}
Summary
For more than sixty years lithium carbonate has been used in medicine. However, during its administration different side effects including oxidative stress can occur. Selenium belongs to essential elements possessing antioxidant properties. This study aimed at evaluating if selenium could be used as a protective adjuvant in lithium therapy. The experiment was performed on four groups of Wistar rats: I (control), II (Li), III (Se), IV (Li + $\mathrm{Se}$ ) treated with saline, lithium carbonate $(2.7 \mathrm{mg} \mathrm{Li} / \mathrm{kg} \mathrm{b.w.),}$ sodium selenite $(0.5 \mathrm{mg} \mathrm{Se} / \mathrm{kg}$ b.w.) and lithium carbonate (2.7 mg Li/kg b.w.) + sodium selenite ( $0.5 \mathrm{mg} \mathrm{Se} / \mathrm{kg}$ b.w.), respectively. All substances were administered as water solutions by stomach tube for 3 or 6 weeks. Catalase (CAT), superoxide dismutase (SOD) and glutathione peroxidase (GPX) as well as malonyldialdehyde (MDA) were determined in brain homogenates. Lithium slightly enhanced MDA and depressed CAT and SOD after 6 weeks as well as GPx after 3 weeks. Selenium co-administration showed tendency to restore the disturbed parameters. Selenium alone and given with lithium significantly increased GPx vs. Li-treated group after 3 weeks. Having regarded the outcomes of this study, the research on application of selenium during lithium treatment seems to be worth continuation.
\end{abstract}

\section{Key words}

Selenium • Lithium • Oxidative stress • Brain • Rats

\section{Corresponding author}

J. Kocot, Chair and Department of Medical Chemistry, Medical University of Lublin, Chodźki 4a, 20-093 Lublin, Poland. Fax: 81535 7390. E-mail: joanna.kocot@umlub.pl

\section{Introduction}

For more than sixty years lithium salts have been widely used in different fields of medicine, first of all in psychiatry (Scheuch et al. 2010, Ahmad et al. 2011, Banerjee et al. 2012, Albayrak et al. 2013, Bauer et al. 2014). However, the promising outcomes concerning the possibility of its application in neurology (Camins et al. 2009, Ozkul et al. 2014) or in patients with thyroid diseases undergoing radioiodine therapy (Bogazzi et al. 2010) have also been reported. As lithium shows its beneficial action only within a strongly determined range (Vijaimohan et al. 2010, Singh et al. 2013, Smith et al. 2014) its administration must be applied taking appropriate precautions. An overrun of the safe threshold can result in different side effects including disturbances of nervous and alimentary system as well as disorders of kidneys, eyes and glands (Oktem et al. 2005, Saunders et al. 2009, Ahmad et al. 2011, Broberg et al. 2011, Eskandari et al. 2012). Our previous studies have shown changes of antioxidant activity in rats exposed to lithium (Kiełczykowska et al. 2008). Other scientists have also found the influence of lithium administration on oxidant processes (Bhalla et al. 2007, Malhotra and Dhawan 2008, Nciri et al. 2008, Eskandari et al. 2012, Ozkul et al. 2014). These observations provoked research on the use of essential metals or natural substances possessing antioxidant properties as protective agents against lithium toxicity (Chadha et al. 2008, Malhotra and Dhawan 2008, Vijaimohan et al. 2010). The contamination of the environment with lithium resulting from disposing of spent lithium batteries (Aral and Vecchio-Sadus 2008) as well as the fact that potential supplementation of drinking 
water with lithium has been considered (Giotakos et al. 2013) suggest that such investigations could be worth undertaking.

Selenium belongs to essential microelements. Being a constituent of one of the main antioxidant enzymes - glutathione peroxidase - it is considered to be an antioxidant (Brüning et al. 2012, El-Demerdash and Nasr 2014, El-Boshy et al. 2015). Its possible application as a protective agent against toxic metals and compounds as well as against oxidative stress have already been studied and the outcomes have seemed to be encouraging (El-Demerdash 2004, Selamoglu Talas et al. 2009, El-Demerdash and Nasr 2014, Jebur et al. 2014, El-Boshy et al. 2015). Selenium alone or in combination with vitamin $\mathrm{E}$ has already been found to prevent oxidative stress in brain of animals exposed to cigarette smoke (Ozkan et al. 2007), chromium (Soudani et al. 2012) and mercury (Glaser et al. 2013).

Having regarded the presented facts we formulated a hypothesis that selenium could be administered to patients undergoing lithium therapy to alleviate side effects, particularly those related to oxidant stress. Relationships between selenium intake and functions of nervous system have already been reported (Benton 2002). In the current study the inorganic sodium selenite was chosen as it is still used in animal studies (Sreekala and Indira 2009, Loeschner et al. 2014) as well as in clinical practice (Savory et al. 2012, Beuth et al. 2013).

The present study was performed with the aim of evaluation if selenium in its inorganic form (sodium selenite) could exert beneficial influence on chosen oxidative parameters in brain of rats receiving lithium.

\section{Materials and Methods}

\section{Animals}

The experiment was carried out on adolescent male Wistar rats (48 animals, 130-160 g body weight). Rats had free access to standard feed and drinking water. The study was performed according to statutory bioethical standards and approved by Local Ethical Commission of Medical University of Lublin, acceptance no.1/2013.

\section{Experimental design}

After an acclimatization period of three days the animals were randomly divided into four groups (twelve animals each): group I (control) - treated with saline; group II (Li) - treated with lithium (as $\left.\mathrm{Li}_{2} \mathrm{CO}_{3}\right)$ at a dose of $2.7 \mathrm{mg} \mathrm{Li} / \mathrm{kg} \mathrm{b.w.;} \mathrm{group} \mathrm{III}(\mathrm{Se})$ - treated with selenium (as $\mathrm{Na}_{2} \mathrm{SeO}_{3}$ ) at a dose of $0.5 \mathrm{mg} \mathrm{Se} / \mathrm{kg}$ b.w.; group IV $(\mathrm{Li}+\mathrm{Se})$ - treated simultaneously with lithium $\left(\mathrm{Li}_{2} \mathrm{CO}_{3}\right)$ and selenium $\left(\mathrm{Na}_{2} \mathrm{SeO}_{3}\right)$ at a dose of $2.7 \mathrm{mg}$ $\mathrm{Li} / \mathrm{kg}$ b.w. and of $0.5 \mathrm{mg} \mathrm{Se} / \mathrm{kg}$ b.w., respectively. The administration was performed in form of water solutions by stomach tube. The compounds were given for a period of three or six weeks, once a day. Body mass of each animal was measured every day before administration and the appropriate amount of selenium and/or lithium solutions was calculated. After 3 weeks a half of rats of each group and after 6 weeks the rest of the animals were sacrificed under thiopental narcosis and samples of brain were collected. Ten per cent (w/v) tissue homogenates were prepared in $0.1 \mathrm{~mol} \mathrm{dm}{ }^{-3}$ Tris- $\mathrm{HCl}$ buffer, $\mathrm{pH}=7.4$. Supernatants were obtained by centrifugation at $5000 \mathrm{xg}$ for $30 \mathrm{~min}$.

\section{Biochemical investigations}

The following oxidant parameters were determined in brain homogenates: activities of antioxidant enzymes - catalase (CAT), superoxide dismutase (SOD) and glutathione peroxidase (GPx) as well as the concentration of a lipid peroxidation marker malonyldialdehyde (MDA). CAT activity was measured using a spectrophotometric method described by Góth (1991) and expressed in U of CAT/mg of protein. SOD and GPx activities were determined using diagnostic kits RANSOD and RANSEL produced by RANDOX and expressed in $\mathrm{U}$ of SOD/mg of protein and $\mathrm{U}$ of GPx/g of protein, respectively. Malonyldialdehyde (MDA) concentration was determined using method of Ledwożyw et al. (1986) and expressed in mmol of $\mathrm{MDA} / \mathrm{g}$ of protein. Protein was measured using method of Bradford (1976). The assays were performed with use of spectrophotometer SPECORD M40 (Zeiss Jena).

\section{Statistics}

All statistical analyses were performed using STATISTICA program (version 10.0). The normality of data distribution was verified using Shapiro-Wilk test. The differences among the studied groups were analyzed using a one-way analysis of variance (ANOVA), followed by Tukey test (for normally distributed variables) or Kruskal-Wallis one way analysis of variance (for non-normally distributed variables). Values were considered significant with $\mathrm{p}<0.05$. 

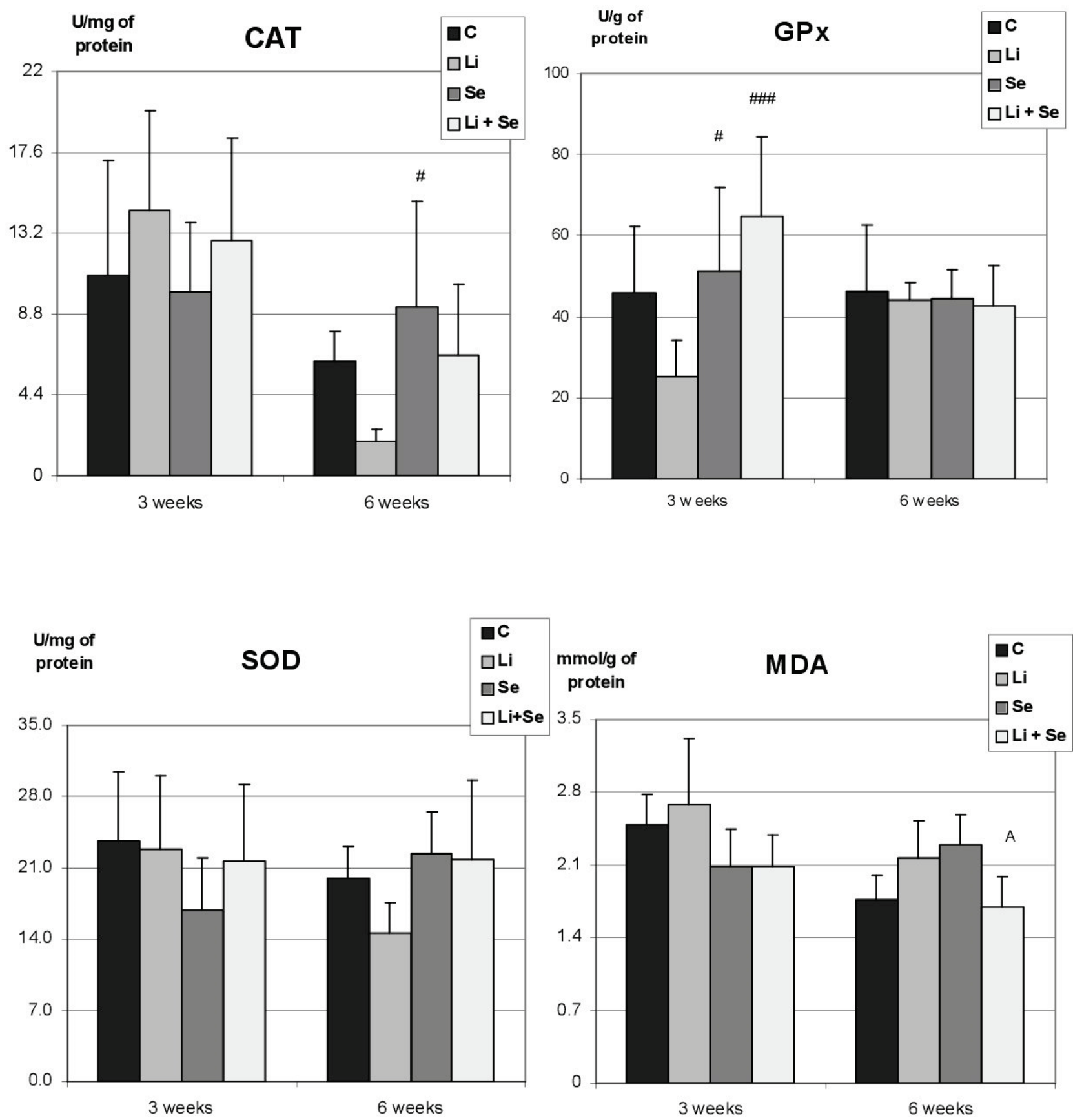

Fig. 1. CAT, GPX and SOD activity as well as MDA concentration in brain of rats receiving lithium and/or selenium. ${ }^{A}$ significantly different vs. Se group $\mathrm{p}<0.05 ;{ }^{\#}$ significantly different vs. Li group $\mathrm{p}<0.05 ;{ }^{\# \# \#}$ significantly different vs. Li group $p<0.001$.

\section{Results}

After 3 weeks of experiment there were not distinct differences in CAT activity among the studied groups. After 6 weeks lithium slightly depressed CAT compared to control while selenium co-administration restored CAT activity. Selenium alone caused significant increase vs. Li-treated group ( $p=0.0284)$.

After 3 weeks in rats receiving lithium alone
GPx was insignificantly depressed vs. control. Selenium alone and given with lithium significantly increased GPx vs. Li-treated group $(\mathrm{p}=0.0351$ and $\mathrm{p}=0.0008$, respectively). After 6 weeks the obtained values of GPx activity did not show any differences among all studied groups.

SOD activity did not markedly differ after both 3 and 6 weeks. However, a slight tendency to depletion in Li-treated rats vs. control, accompanied by restoration 
tendency in $\mathrm{Li}+$ Se group was observed after 6 weeks.

MDA concentration after 3 weeks did not display significant differences. However selenium alone and given with lithium slightly depressed MDA in comparison with control and Li-treated group. After 6 weeks selenium given with lithium caused significant decrease when compared with Se-group $(p=0.0235)$.

All the presented results are collected in Figure 1.

\section{Discussion}

Oxidative and nitrosative processes have been found to be involved into pathogenesis of diverse illnesses, including psychiatric ones (Savory et al. 2012, de Sousa et al. 2014a, b). Due to this fact the growing concern in possible application of antioxidant substances in preventing disorders of organism is being observed (Oktem et al. 2005, Chadha et al. 2008, El-Boshy et al. 2015).

The research on the effect of lithium on oxidant balance has revealed quite divergent results. Some authors have stated that lithium may exert antioxidant action (Banerjee et al. 2012, Albayrak et al. 2013, de Sousa et al. 2014b), whereas other scientists have reported contradicting results (Oktem et al. 2005, Ahmad et al. 2011, Eskandari et al. 2012). Furthermore, Nciri et al. (2008) showed that pro-oxidative action of lithium can differ, depending on the studied organ.

The attempts towards the application of bioelements and substances of natural origin possessing antioxidant properties as protective agents against lithium toxicity have already been made and the obtained results seem to be promising (Oktem et al. 2005, Bhalla et al. 2007, Chadha et al. 2008, Malhotra and Dhawan 2008, Vijaimohan et al. 2010).

In the current study lithium caused depletion of CAT and SOD after 6 weeks as well as GPx after 3 weeks. MDA was slightly increased. The obtained results are partially consistent with those reported by other authors.

Similarly as in the present experiment, GPx, SOD and CAT were not significantly altered in brain of mice receiving lithium carbonate in diet during 1- and 3-month-experiment (Riadh et al. 2011). In mice receiving lithium intraperitoneally no significant effect on brain CAT and GPx was observed (Nciri et al. 2008). No significant effect of dietary lithium on GPx and SOD was observed in hypothalamus and hippocampus of rats under normal condition, whereas in stressed animals GPx was not disturbed and SOD markedly increased (de Vasconcellos et al. 2006). Lithium pretreatment caused significant decrease in CAT and SOD in brain of rats treated with ouabain (Brüning et al. 2012). Several studies revealed that the influence of lithium on brain SOD can depend on the studied part. In rats receiving lithium cerebrum SOD was enhanced, whereas in cerebellum no changes were observed (Bhalla et al. 2007). On the other hand, lithium given to rats treated with aluminium significantly decreased CAT and SOD activities in cerebrum and cerebellum (Bhalla and Dhawan 2009). Fourteen-day-treatment with lithium markedly decreased SOD in prefrontal cortex and caused no changes in hippocampus, whereas in the case of CAT a slight, insignificant decrease was observed irrespective of the studied region (Frey et al. 2006). The differences in lithium influence on the SOD depending on the studied region of brain were also reported by Souza et al. (2014) who found no effect of lithium treatment on SOD in cerebral cortex, whereas in hippocampus significant decrease was observed. Interestingly, in the case of CAT and GPx no changes were observed in both studied regions.

Dietary lithium caused no significant changes of TBARS in rats (de Vasconcellos et al. 2006). The similar results were obtained in brain of mice receiving intraperitoneal injection of lithium carbonate (Nciri et al. 2008) as well as in brain of mice given lithium in diet (Riadh et al. 2011). Bhalla et al. (2007) observed significant increase in lipid peroxidation in cerebrum and cerebellum of rats treated with lithium. Short-term (14 days) lithium treatment resulted in no significant alterations of MDA in prefrontal cortex and hippocampus of rats (Frey et al. 2006).

In the current experiment selenium alone did not cause significant changes vs. control. Other scientists reported rather divergent results. In hippocampus of rats receiving DL-selenomethionine and exposed to mercury hippocampal SOD and MDA were found to be markedly increased ( $\mathrm{Su}$ et al. 2008). Sreekala and Indira (2009) in turn found that sodium selenite depressed MDA and enhanced SOD, CAT and GPx in brain of rats. In brain of rats exposed to a carcinogenic substance selenium administered in organic form diminished MDA and increased CAT, SOD and GPx (Selamoglu Talas et al. 2008). GPx and SOD was practically unchanged, whereas CAT increased in brain of mice exposed to cigarette smoke and receiving seleno-L-methionine for 3 months. 
The lengthening of the experiment period up to 5 months resulted in unchanged CAT and increased SOD and GPX (Ozkan et al. 2007). Selenium did not affect cortex brain GPx in rats (Naziroğlu et al. 2008). In mice treated with inorganic sodium selenite brain GPx was markedly increased while no significant effect was observed in those treated with methylmercury. TBARS was significantly enhanced by Se-administration both in animals without any other treatment and in those treated by methylmercury (Glaser et al. 2010). In contrast, in mice treated with organic selenium (diphenyl diselenide) cortical mitochondrial GPx was not altered while MDA was significantly depressed. The same results were shown in mice exposed to methylmercury (Glaser et al. 2013). Ghodbane et al. (2011) observed no significant influence of inorganic selenium on brain GPx in mice. However, in animals additionally subjected to static magnetic field a slight increase was noted.

There is not too much data concerning relationships between lithium and selenium. However, some studies have revealed interesting outcomes. The positive correlation between urinary selenium and $\mathrm{T}_{4}$ and negative one between lithium urinary concentration and plasma free $T_{4}$ level were found in women inhabiting in areas of high lithium level in drinking water (Broberg et al. 2011). Some selenoorganic compounds have been found to show lithium-mimetic properties (Brüning et al.
2012, Singh et al. 2013). In the current study selenium given together with lithium did not markedly disturb any studied parameter in rat brain when compared with control group. Although the majority of the observed changes were insignificant, co-administration of selenium seems to display a tendency to restoration action in the case of parameters slightly altered by lithium alone (GPx after 3 weeks and the other studied parameters after 6 weeks). The obtained results are consistent with those obtained in our previous study in blood (Kiełczykowska et al. 2014).

\section{Conclusion}

The obtained results let suggest that this pilot study resulted in encouraging outcomes as the disturbances observed in Li-given rats were restored by co-administration of selenium. Having regarded the presented studies concerning the application of other (organic) forms of selenium, further studies could also include organic selenium compounds which have already been investigated in regard to their possible use as Se-supplements (Musik et al. 2013).

\section{Conflict of Interest}

There is no conflict of interest.

\section{References}

AHMAD M, ELNAKADY Y, FAROOQ M, WADAAN M: Lithium induced toxicity in rats: blood serum chemistry, antioxidative enzymes in red blood cells and histopathological studies. Biol Pharm Bull 34: 272-277, 2011.

ALBAYRAK A, HALICI Z, POLAT B, KARAKUS E, CADIRCI E, BAYIR Y, KUNAK S, KARCIOGLU SS, YIGIT S, UNAL D, ATAMANALP SS: Protective effects of lithium: a new look at an old drug with potential antioxidative and anti-inflammatory effects in an animal model of sepsis. Int Immunopharmacol 16: 35-40, 2013.

ARAL H, VECCHIO-SADUS A: Toxicity of lithium to humans and the environment - a literature review. Ecotoxicol Environ Saf 70: 349-356, 2008.

BANERJEE U, DASGUPTA A, ROUT JK, SINGH OP: Effects of lithium therapy on $\mathrm{Na}^{+}-\mathrm{K}^{+}$-ATPase activity and lipid peroxidation in bipolar disorder. Prog Neuropsychopharmacol Biol Psychiatry 37: 56-61, 2012.

BAUER M, ADLI M, RICKEN R, SEVERUS E, PILHATSCH M: Role of lithium augmentation in the management of major depressive disorder. CNS Drugs 28: 331-342, 2014.

BENTON D: Selenium intake, mood and other aspects of psychological functioning. Nutr Neurosci 5: 363-374, 2002.

BEUTH J, VAN LEENDERT R, SCHNEIDER B, UHLENBRUCK G: Complementary medicine on side-effects of adjuvant hormone therapy in patients with breast cancer. In Vivo 27: 869-871, 2013.

BHALLA P, DHAWAN DK: Protective role of lithium in ameliorating the aluminium-induced oxidative stress and histological changes in rat brain. Cell Mol Neurobiol 29: 513-521, 2009.

BHALLA P, CHADHA VD, DHAR R, DHAWAN DK: Neuroprotective effects of zinc on antioxidant defense system in lithium treated rat brain. Indian J Exp Biol 45: 954-958, 2007. 
BOGAZZI F, GIOVANNETTI C, FESSEHATSION R, TANDA ML, CAMPOMORI A, COMPRI E, ROSSI G, CECCARELLI C, VITTI P, PINCHERA A, BARTALENA L, MARTINO E: Impact of lithium on efficacy of radioactive iodine therapy for Graves' disease: a cohort study on cure rate, time to cure, and frequency of increased serum thyroxine after antithyroid drug withdrawal. J Clin Endocrinol Metab 95: 201-208, 2010.

BRADFORD MM: A rapid and sensitive method for the quantitation of microgram quantities of protein utilizing the principle of protein-dye binding. Anal Biochem 72: 248-254, 1976.

BROBERG K, CONCHA G, ENGSTRÖM K, LINDVALL M, GRANDÉR M, VAHTER M: Lithium in drinking water and thyroid function. Environ Health Perspect 119: 827-830, 2011.

BRÜNING CA, PRIGOL M, LUCHESE C, PINTON S, NOGUEIRA CW: Diphenyl diselenide ameliorates behavioral and oxidative parameters in an animal model of mania induced by ouabain. Prog Neuropsychopharmacol Biol Psychiatry 38: 168-174, 2012.

CAMINS A, VERDAGUER E, JUNYENT F, YESTE-VELASCO M, PELEGRÍ C, VILAPLANA J, PALLÁS M: Potential mechanisms involved in the prevention of neurodegenerative diseases by lithium. CNS Neurosci Ther 15: 333-344, 2009.

CHADHA VD, BHALLA P, DHAWAN DK: Zinc modulates lithium-induced hepatotoxicity in rats. Liver Int 28: 558$565,2008$.

DE SOUSA RT, ZANETTI MV, BUSATTO GF, MOURO MG, ZARATE CA Jr, GATTAZ WF, HIGA EM, MACHADO-VIEIRA R: Lithium increases nitric oxide levels in subjects with bipolar disorder during depressive episodes. J Psychiatr Res 55: 96-100, 2014a.

DE SOUSA RT, ZARATE CA Jr, ZANETTI MV, COSTA AC, TALIB LL, GATTAZ WF, MACHADO-VIEIRA R: Oxidative stress in early stage Bipolar Disorder and the association with response to lithium. $J$ Psychiatr Res 50: $36-41,2014 b$.

DE VASCONCELLOS AP, NIETO FB, CREMA LM, DIEHL LA, DE ALMEIDA LM, PREDIGER ME, DA ROCHA ER, DALMAZ C: Chronic lithium treatment has antioxidant properties but does not prevent oxidative damage induced by chronic variate stress. Neurochem Res 31: 1141-1151, 2006.

EL-BOSHY ME, RISHA EF, ABDELHAMID FM, MUBARAK MS, HADDA TB: Protective effects of selenium against cadmium induced hematological disturbances, immunosuppressive, oxidative stress and hepatorenal damage in rats. J Trace Elem Med Biol 29: 104-110, 2015.

EL-DEMERDASH FM: Antioxidant effect of vitamin E and selenium on lipid peroxidation, enzyme activities and biochemical parameters in rats exposed to aluminium. J Trace Elem Med Biol 18: 113-121, 2004.

EL-DEMERDASH FM, NASR HM: Antioxidant effect of selenium on lipid peroxidation, hyperlipidemia and biochemical parameters in rats exposed to diazinon. J Trace Elem Med Biol 28: 89-93, 2014.

ESKANDARI MR, FARD JK, HOSSEINI MJ, POURAHMAD J: Glutathione mediated reductive activation and mitochondrial dysfunction play key roles in lithium induced oxidative stress and cytotoxicity in liver. Biometals 25: 863-873, 2012.

FREY BN, VALVASSORI SS, RÉUS GZ, MARTINS MR, PETRONILHO FC, BARDINI K, DAL-PIZZOL F, KAPCZINSKI F, QUEVEDO J: Effects of lithium and valproate on amphetamine-induced oxidative stress generation in an animal model of mania. $J$ Psychiatry Neurosci 31: 326-332, 2006.

GHODBANE S, AMARA S, GARREL C, ARNAUD J, DUCROS V, FAVIER A, SAKLY M, ABDELMELEK H: Selenium supplementation ameliorates static magnetic field-induced disorders in antioxidant status in rat tissues. Environ Toxicol Pharmacol 31: 100-106, 2011.

GIOTAKOS O, NISIANAKIS P, TSOUVELAS G, GIAKALOU VV: Lithium in the public water supply and suicide mortality in Greece. Biol Trace Elem Res 156: 376-379, 2013.

GLASER V, NAZARI EM, MÜLLER YM, FEKSA L, WANNMACHER CM, ROCHA JB, DE BEM AF, FARINA M, LATINI A: Effects of inorganic selenium administration in methylmercury-induced neurotoxicity in mouse cerebral cortex. Int J Dev Neurosci 28: 631-637, 2010.

GLASER V, MORITZ B, SCHMITZ A, DAFRÉ AL, NAZARI EM, RAUH MÜLLER YM, FEKSA L, STRALIOTTOA MR, DE BEM AF, FARINA M, DA ROCHA JB, LATINI A: Protective effects of diphenyl diselenide in a mouse model of brain toxicity. Chem Biol Interact 206: 18-26, 2013. 
GÓTH L: A simple method for determination of serum catalase activity and revision of reference range. Clin Chim Acta 196: 143-151, 1991.

JEBUR AB, NASR HM, EL-DEMERDASH FM: Selenium modulates $\beta$-cyfluthrin-induced liver oxidative toxicity in rats. Environ Toxicol 29: 1323-1329, 2014.

KIEŁCZYKOWSKA M, MUSIK I, PASTERNAK K: Relationships between silicon content and glutathione peroxidase activity in tissues of rats receiving lithium in drinking water. Biometals 21: 53-59, 2008.

KIEŁCZYKOWSKA M, KOCOT J, KURZEPA J, LEWANDOWSKA A, ŻELAZOWSKA R, MUSIK I: Could selenium administration alleviate the disturbances of blood parameters caused by lithium administration in rats? Biol Trace Elem Res 158: 359-364, 2014.

LEDWOŻYW A, MICHALAK J, STĘPIEŃ A, KĄDZIOŁKA A: The relationships between plasma triglycerides, cholesterol, total lipids and lipid peroxidation products during human atherosclerosis. Clin Chim Acta 155: 275-283, 1986.

LOESCHNER K, HADRUP N, HANSEN M, PEREIRA SA, GAMMELGAARD B, MØLLER LH, MORTENSEN A, LAM HR, LARSEN EH: Absorption, distribution, metabolism and excretion of selenium following oral administration of elemental selenium nanoparticles or selenite in rats. Metallomics 6: 330-337, 2014.

MALHOTRA A, DHAWAN DK: Zinc improves antioxidative enzymes in red blood cells and hematology in lithiumtreated rats. Nutr Res 28: 43-50, 2008.

MUSIK I, KIEŁCZYKOWSKA M, KOCOT J: Oxidant balance in brain of rats receiving different compounds of selenium. Biometals 26: 763-771, 2013.

NAZIROĞLU M, KUTLUHAN S, YILMAZ M: Selenium and topiramate modulates brain microsomal oxidative stress values, $\mathrm{Ca}^{2+}$-ATPase activity, and EEG records in pentylentetrazol-induced seizures in rats. J Membr Biol 225: 39-49, 2008.

NCIRI R, ALLAGUI MS, CROUTE F, VINCENT C, ELFEKI A: Effects of low doses of Li carbonate injected into mice. Functional changes in kidney seem to be related to the oxidative status. (in French) C R Biol 331: 23-31, 2008.

OKTEM F, OZGUNER F, SULAK O, OLGAR S, AKTURK O, YILMAZ HR, ALTUNTAS I: Lithium-induced renal toxicity in rats: protection by a novel antioxidant caffeic acid phenethyl ester. Mol Cell Biochem 277: 109-115, 2005.

OZKAN A, FISKIN K, AYHAN AG: Effect of vitamin E and selenium on antioxidant enzymes in brain, kidney and liver of cigarette smoke-exposed mice. Biologia 62: 360-364, 2007.

OZKUL A, SAIR A, AKYOL A, YENISEY C, DOST T, TATAROGLU C: Effects of lithium and lamotrigine on oxidative-nitrosative stress and spatial learning deficit after global cerebral ischemia. Neurochem Res 39: 853861, 2014.

RIADH N, ALLAGUI MS, BOUROGAA E, VINCENT C, CROUTE F, ELFEKI A: Neuroprotective and neurotrophic effects of long term lithium treatment in mouse brain. Biometals 24: 747-757, 2011.

SAUNDERS BD, SAUNDERS EF, GAUGER PG: Lithium therapy and hyperparathyroidism: an evidence-based assessment. World J Surg 33: 2314-2323, 2009.

SAVORY LA, KERR CJ, WHITING P, FINER N, MCENENY J, ASHTON T: Selenium supplementation and exercise: effect on oxidant stress in overweight adults. Obesity (Silver Spring) 20: 794-801, 2012.

SCHEUCH K, HÖLTJE M, BUDDE H, LAUTENSCHLAGER M, HEINZ A, AHNERT-HILGER G, PRILLER J: Lithium modulates tryptophan hydroxylase 2 gene expression and serotonin release in primary cultures of serotonergic raphe neurons. Brain Res 1307: 14-21, 2010.

SELAMOGLU TALAS Z, OZDEMIR I, YILMAZ I, GOK Y, ORUN I: The investigation of the antioxidative properties of the novel synthetic organoselenium compounds in some rat tissues. Exp Biol Med (Maywood) 233: 575-579, 2008.

SELAMOGLU TALAS Z, YILMAZ I, OZDEMIR I, ATES B, GOK Y, CETINKAYA B: Role of synthesized organoselenium compounds on protection of rat erythrocytes from DMBA-induced oxidative stress. Biol Trace Elem Res 128: 167-175, 2009. 
SINGH N, HALLIDAY AC, THOMAS JM, KUZNETSOVA OV, BALDWIN R, WOON EC, ALEY PK, ANTONIADOU I, SHARP T, VASUDEVAN SR, CHURCHILL GC: A safe lithium mimetic for bipolar disorder. Nat Commun 4: 1332, 2013.

SMITH AJ, KIM SH, TAN J, SNEED KB, SANBERG PR, BORLONGAN CV, SHYTLE RD: Plasma and brain pharmacokinetics of previously unexplored lithium salts. RSC Adv 4: 12362-12365, 2014.

SOUDANI N, TROUDI A, AMARA IB, BOUAZIZ H, BOUDAWARA T, ZEGHAL N: Ameliorating effect of selenium on chromium (VI)-induced oxidative damage in the brain of adult rats. J Physiol Biochem 68: 397 409, 2012.

SOUZA LC, WILHELM EA, BORTOLATTO CF, NOGUEIRA CW, BOEIRA SP, JESSE CR: The protective effect of melatonin against brain oxidative stress and hyperlocomotion in a rat model of mania induced by ouabain. Behav Brain Res 271: 316-324, 2014.

SREEKALA S, INDIRA M: Impact of co administration of selenium and quinolinic acid in the rat's brain. Brain Res 1281: 101-107, 2009.

SU L, WANG M, YIN ST, WANG HL, CHEN L, SUN LG, RUAN DY: The interaction of selenium and mercury in the accumulations and oxidative stress of rat tissues. Ecotoxicol Environ Saf 70: 483-489, 2008.

VIJAIMOHAN K, MALLIKA J, SHYAMALA DEVI CS: Chemoprotective effect of sobatum against lithium-induced oxidative damage in rats. $J$ Young Pharm 2: 68-73, 2010. 